\author{
Katarzyna Janczulewicz \\ Biblioteka Główna \\ Śląski Uniwersytet Medyczny w Katowicach \\ Instytut Nauk o Kulturze \\ Uniwersytet Śląski w Katowicach \\ e-mail: k.janczulewicz@gmail.com \\ (D) https://orcid.org/0000-0001-9321-3192
}

\title{
Biblioteka Uniwersytetu Śląskiego \\ w pięćdziesięciolecie istnienia / red. Maria Kycler, Dariusz Pawelec, Bogumiła Warząchowska. - Katowice : Oficyna Wydawnicza Waclaw Walasek, 2018. - 415, [1] s. : il. czarno-białe, $20 \times 20 \mathrm{~cm}$. - (Biblioteka Otwarta). - ISBN 978-83-65694-58-4
}

Złoty jubileusz instytucji stanowi znakomitą okazję do podsumowań dotychczasowej działalności. W 2018 r. pięćdziesiątą rocznicę istnienia obchodził Uniwersytet Śląski w Katowicach, a wraz z nim Biblioteka Uniwersytetu Śląskiego (dalej: BUŚ). Z tej okazji przygotowano publikację podsumowującą historię i dotychczasową działalność Biblioteki: Biblioteka Uniwersytetu Śląskiego w pięćdziesięciolecie istnienia pod redakcją Marii Kycler, Dariusza Pawelca i Bogumiły Warząchowskiej, z rozdziałami opracowanymi przez pracowników Biblioteki. Książka ukazała się w serii „Biblioteka Otwarta”, w której wydano też księgę jubileuszową z okazji czterdziestolecia BUŚ Biblioteka otwarta. Wczoraj i jutro Biblioteki Uniwersytetu Ślaskiego (Katowice 2008), pokonferencyjny tom Światła biblioteki otwartej: rola biblioteki akademickiej w kształtowaniu społeczeństwa obywatelskiego (Katowice 2016). Kolekcję jubileuszowych publikacji uzupełniają następujące książki: Biblioteki specjalistyczne Uniwersytetu Ślaskiego w Katowicach (Katowice 2018) oraz Kolekcje w zbiorach bibliotek Uniwersytetu Ślaskiego w Katowi- 
cach (Katowice 2018). Tym samym czytelnicy otrzymali pełen obraz działalności bibliotecznej Uniwersytetu Śląskiego, z historią bibliotek specjalistycznych i najciekawszych zbiorów w nich zgromadzonych.

Poza artykułami omawiającymi historyczne i współczesne aspekty działalności Biblioteki tom uzupełnia indeks osobowy oraz sylwetki dyrektorów BUŚ: Piotra Stasiaka, Jerzego Ratajewskiego, Henryka Kota, Włodzimierza Goriszowskiego, Antoniego Molendy, Wandy Dziadkiewicz i Dariusza Pawelca, wraz z bibliografią podmiotowo-przedmiotową każdej z wymienionych osób.

We Wstepie dyrektor Biblioteki D. Pawelec odwołał się do publikacji wydanej z okazji czterdziestolecia BUŚ, przypominając wieloletnie problemy lokalizacyjne Biblioteki oraz wyrażone 10 lat wcześniej nadzieje na zmianę tej sytuacji i pragnienia, by okrągły jubileusz obchodzić w nowej siedzibie.

Dwa pierwsze rozdziały publikacji można potraktować jako wstępne omówienie historii i struktury BUŚ. W otwierającym rozdziale Historia Biblioteki Uniwersytetu Ślaskiego (1968-2017) Jadwiga Witek i Katarzyna Wyszyńska przedstawiły dzieje Biblioteki od założenia uczelni do chwili obecnej, gdy działania BUŚ realizowane są w ramach CINiBA Centrum Informacji Naukowej i Biblioteki Akademickiej, projektu Uniwersytetu Śląskiego i Uniwersytetu Ekonomicznego w Katowicach. Autorki sporządziły liczne kalendaria wydarzeń, wykresy i zestawienia danych obrazujące aktywności Biblioteki. Ukazały z jednej strony funkcjonowanie biblioteki akademickiej jako zaplecza naukowego i warsztatu informacyjnego Uniwersytetu, z drugiej - przeobrażenie Biblioteki w nowoczesne centrum informacji. Tematykę zmian w strukturze organizacyjnej biblioteki podjęła K. Wyszyńska w rozdziale Struktura organizacyjna systemu biblioteczno-informacyjnego Uniwersytetu Śląskiego po roku 2004. Autorka scharakteryzowała funkcjonowanie systemu biblioteczno-informacyjnego oraz biblioteki centralnej - BUŚ (wcześniej Biblioteki Głównej Uniwersytetu Śląskiego).

Tworzenie warsztatu pracy naukowej polega na pozyskiwaniu zbiorów: książek, czasopism naukowych, baz danych. Zagadnienia przygotowywania kolekcji bibliotecznych i zarządzania nimi zostały zanalizowane w czterech rozdziałach. Iwona Blicharska w rozdziale Gromadzenie zbiorów w Bibliotece Uniwersytetu Śląskiego - kontynuacja i zmiany omówiła politykę gromadzenia zbiorów w BUŚ i współpracę z czytelnikami. Szczególny rodzaj pozyskiwania zbiorów bibliotecznych scharakteryzowały Romana Nowak i Sylwia Szabucka w rozdziale Wymiana krajowa i zagraniczna $w$ Bibliotece Uniwersytetu Ślaskiego $w$ latach 2008-2016 - nowe doświadczenia. Autorki podsumowały zmiany za- 
chodzące w zakresie międzyinstytucjonalnej wymiany zbiorów na przestrzeni ostatnich lat oraz przedstawiły moduł Wymiana i Dary, stanowiący integralną część systemu bibliotecznego PROLIB. Przygotowały zestawienia liczbowe i wykresy ilustrujące kształtowanie się wymiany na tle innych sposobów pozyskiwania materiałów bibliotecznych. Najciekawsze pod względem formalnym kolekcje zbiorów zaprezentowała Marzena Smyłła w rozdziale Zbiory specjalne Biblioteki Uniwersytetu Śląskiego. Autorka przybliżyła historię Oddziału Zbiorów Specjalnych (obecnie Pracownia Zbiorów Specjalnych) oraz dokonała przeglądu wybranych kolekcji: starych druków, księgozbiorów Żuławskich, kolekcji Franciszki i Stefana Themersonów. Opracowanie zbiorów jest niezwykle ważną czynnością w procesie tworzenia katalogów i właściwej prezentacji zbiorów. Zmiany w zakresie katalogowania formalnego i opracowania rzeczowego, konwersja katalogów od kartkowych i klamrowych do elektronicznego - to tematy podjęte przez Martę Błeszyńską w rozdziale Opracowanie wydawnictw zwartych $w$ Bibliotece Uniwersytetu Ślaskiego - wybrane zagadnienia. Autorka omówiła również historyczne przekształcenia w Oddziale Opracowania Zbiorów oraz przedstawiła, na czym polega współpraca z Katalogiem Centralnym NUKAT i przygotowanie sygnatur księgozbioru do wolnego dostępu.

Druga część zebranych w tomie materiałów została poświęcona pracom bibliotecznym w zakresie udostępniania materiałów bibliotecznych dla czytelników i ich prezentacji. Tradycyjną kulturę organizacyjną BUŚ wzbogaciły nowe metody zarządzania zbiorami i usługami. Biblioteka to nie tylko centrum wiedzy, ale też miejsce spotkań, integracji i rozwoju intelektualnego. W pierwszym rozdziale tej części publikacji, zatytułowanym $Z$ organizacji przechowywania i udostęniania zbiorów w Centrum Informacji Naukowej i Bibliotece Akademickiej, Janina Wieczorek nakreśliła zasygnalizowane przez D. Pawelca problemy związane z lokalizacją Biblioteki Głównej, w tym inwestycje w nową siedzibę instytucji. Opisała przygotowania, przeprowadzkę i aranżację zbiorów w nowym miejscu, m.in. wdrożenie wolnego dostępu do zbiorów w nowym gmachu. Artykuł uzupełniają fotografie aranżacji i narzędzi informatycznych (panele informacyjne, miejsce samowypożyczeń) oraz plany lokalizacji zbiorów. Z kolei Renata Mateusiak w rozdziale $Z$ problematyki udostępniania prezencyjnego w Centrum Informacji Naukowej i Bibliotece Akademickiej zajęła się tematem udostępniania materiałów na miejscu w bibliotece. Autorka podkreśliła, że Biblioteka jest otwarta nie tylko ze względu na wolny dostęp do zbiorów, ale przede wszystkim dlatego, że z jej usług i materiałów mogą korzystać wszyscy: studenci i pracownicy uczelni w regionie, uczniowie, osoby niezwiązane ze śro- 
dowiskiem akademickim. R. Mateusiak z jednej strony scharakteryzowała oferowane przez Bibliotekę usługi i możliwości, z drugiej ukazała specyfikę pracy bibliotekarzy. Szczególną uwagę poświęciła działaniom informacyjnym i dydaktycznym bibliotekarzy dyżurujących $\mathrm{w}$ strefie wolnego dostępu. Jedną z najpopularniejszych usług bibliotecznych jest wypożyczanie na zewnątrz materiałów. Tematykę tę podjęły R. Mateusiak, Izabela Dziwis-Kika i Katarzyna Pyrek w rozdziale $Z$ zagadnień wypożyczania zbiorów w Centrum Informacji Naukowej $i$ Bibliotece Akademickiej. Dwojaka organizacja zasobów w CINiBA powoduje, że w Bibliotece funkcjonują dwa sposoby wypożyczeń: samoobsługowy dla książek z wolnego dostępu oraz tradycyjna wypożyczalnia jako miejsce odbioru zbiorów zamówionych z magazynu. Autorki przywołały liczne statystyki dotyczące wypożyczeń i czytelników.

Rozwój technologii informacyjnych oraz dostępność nowoczesnych urządzeń wpłynęły pozytywnie na działania bibliotek i oferowane przez nie zasoby, również elektroniczne. W publikacji Biblioteka Uniwersytetu Ślaskiego $w$ pięćdziesięciolecie istnienia troje autorów zaprezentowało doświadczenia Biblioteki z wdrażania procesu automatyzacji usług i oferowanych zbiorów. W rozdziale Udostępnianie baz danych w Bibliotece Uniwersytetu Ślaskiego Aneta Drabek omówiła przemiany w zakresie udostępniania baz danych na Uniwersytecie Śląskim od lat dziewięćdziesiątych ubiegłego stulecia do czasów obecnych. Autorka uwzględniła kolejne systemy i programy: InfoWare CD/HD, IRIS CD Ware, OneLog i HAN. Uzupełnienie tekstu stanowi aneks z wykazem udostępnianych przez BUŚ baz danych z 1996 r. oraz 2017 r. Wieloletnie doświadczenia obejmujące automatyzację procesów bibliotecznych zarysował Andrzej Koziara w rozdziale Automatyzacja procesów informacyjno-bibliotecznych Biblioteki Uniwersytetu Ślaskiego. Autor opisał osiągnięcia pracowników BUŚ w procesie komputeryzacji Biblioteki oraz etapy modernizacji usług elektronicznych świadczonych w CINiBA. Praktykę tworzenia i rozbudowy bazy Bibliografia Dorobku Pracowników Naukowych Uniwersytetu Śląskiego przybliżyła Aleksandra E. Adamczyk w rozdziale Bibliografia Dorobku Pracowników Naukowych Uniwersytetu Ślaskiego - doświadczenia ostatniej dekady. Autorka ukazała proces przetwarzania bazy bibliograficznej w źródło danych referencyjnych dla systemów informacyjnych uczelni i kraju.

Motto biblioteki: „Biblioteka otwarta” jest realizowane wielotorowo, a efekty dotychczasowych działań zaprezentowane zostały w trzech rozdziałach poświęconych zmieniającej się roli bibliotek akademickich we współczesnym świecie. Działalność edukacyjna i kulturotwórcza ma na celu promowanie idei uczenia się przez całe życie i jest jednym 
z systemowych rozwiązań bibliotek w zakresie wyrównywania szans edukacyjnych. A.E. Adamczyk w rozdziale Rola Centrum Informacji Naukowej i Biblioteki Akademickiej w procesie właczania spolecznego scharakteryzowała usprawnienia biblioteczne dla osób z różnymi typami niepełnosprawności: likwidowanie barier architektonicznych, szerokość rozstawienia regałów, aparatura umożliwiająca odbiór treści przez osoby z dysfunkcją wzroku i słuchu. Autorka podkreśliła, że coraz więcej czytelników z dysfunkcjami korzysta ze zbiorów i usług Biblioteki. Proces kształtowania się relacji z otoczeniem zewnętrznym Biblioteki omówiła pierwsza w Polsce rzecznik biblioteki akademickiej J. Witek w rozdziale Akademicka książnica $w$ otoczeniu społecznym - budowanie relacji poprzez działania public relations. Autorka skupiła się na zagadnieniach 50 lat aktywności Biblioteki oraz udoskonalania warsztatu informacyjnego, zaprezentowała też liczne działania adresowane do wszystkich chętnych, nie tylko społeczności akademickiej. M. Kycler, B. Warząchowska i Marta Kunicka w rozdziale Udziat bibliotekarzy Uniwersytetu Śląskiego $w$ działalności stowarzyszeń oraz organizacji zawodowych $i$ naukowych zwróciły uwagę na zaangażowanie pracowników BUŚ w podnoszenie kwalifikacji zawodowych i współpracę środowiskową bibliotek. Bibliotekarze BUŚ nie tylko korzystają z oferty szkoleniowej organizacji bibliotekarskich, ale też czynnie angażują się w pracę na rzecz stowarzyszeń, takich jak: Stowarzyszenie Bibliotekarzy Polskich wraz z Sekcją Bibliotek Szkół Wyższych Stowarzyszenia Bibliotekarzy Polskich, Federacja Bibliotek Kościelnych FIDES, grupy Kierowników Polskich Bibliotek Prawniczych czy Konferencja Dyrektorów Bibliotek Akademickich Szkół Polskich. Ponadto uczestniczą w redagowaniu czasopism naukowych, jak „Bibliotheca Nostra. Śląski Kwartalnik Naukowy”, „Fides. Biuletyn Bibliotek Kościelnych”, publikują prace naukowe w licznych czasopismach i monografiach wieloautorskich.

W ostatnim rozdziale, Działalność naukowo-wydawnicza pracowników Biblioteki Uniwersytetu Śląskiego w Katowicach w latach 20042016, M. Kycler i B. Warząchowska przedstawiły dorobek badawczy i publikacyjny pracowników BUŚ. Opracowana bibliografia za lata 2004-2016 liczy blisko 700 pozycji bibliograficznych i stanowi kontynuację bibliografii wydanej za lata 1968-2003 i zamieszczonej we wcześniejszej księdze jubileuszowej.

W recenzowanym tomie omówiono niemal wszystkie aspekty pracy nowoczesnej biblioteki akademickiej. Jubileusz pięćdziesięciolecia Biblioteki Uniwersytetu Śląskiego stanowi z jednej strony okazję do podsumowania jej historii, z drugiej pozwala z optymizmem patrzeć w przyszłość. Wielowymiarowość tworzących publikację tekstów, liczne 
odwołania do historii BUŚ i tradycji bibliotekarstwa w Polsce pozwalają traktować księgę nie tylko jako jubileuszową pamiątkę, ale jako element edukacyjny w zakresie bibliotekoznawstwa. Liczne ilustracje, zestawienia historyczne i statystyczne pokazują skalę podejmowanych w Bibliotece działań.

Tekst wptynąt do redakcji 23 maja 2019 r. 